\title{
Quality of Prospective Physical Education Teacher Reviewed from Effectiveness of Learning
}

\author{
Setiyo Hartoto \\ Universitas Negeri Surabaya \\ Surabaya, Indonesia \\ setiyohartoto@unesa.ac.id \\ Fifukha Dwi Khory \\ Universitas Negeri Surabaya \\ Surabaya, Indonesia \\ fifukhakhory@unesa.ac.id
}

\author{
Sudarso \\ Universitas Negeri Surabaya \\ Surabaya, Indonesia \\ sudarso@unesa.ac.id \\ Bayu Budi Prakoso \\ Universitas Negeri Surabaya \\ Surabaya, Indonesia \\ bayuprakoso@unesa.ac.id
}

\begin{abstract}
Teacher quality is the key to learning quality. Improving the quality of teacher means improving the quality of learning. Physical Education Teacher Education (PETE) is the principal agency that is most responsible for the quality of teachers through the establishment of prospective PE teachers (PPET) in universities. The learning management program becomes an important program of PETE to improve the quality of PPET, especially in conducting lessons. To measure the success of learning management program, it is necessary to measure the quality of learning conducted by PPET while at partner schools. A total of 290 students and 7 supervising teachers provide an assessment of the quality of learning conducted by 10 PPET. Students assessed using Formative Class Evaluation (FCE) questionnaires while supervising teachers through observation. FCE score of 2.80 (excellent) and observation score of $89.7 \%$ (excellent). The quality of these PPET shows that PETE has succeeded in teaching students to be able to create excellent learning. In addition, the process of assessing the effectiveness of learning using FCE and observation by supervising teacher is expected to provide experience to PPET on how to conduct selfevaluation in improving the quality of learning.
\end{abstract}

Keywords-quality of prospective $P E$ teachers; $F C E$ score; observation score; supervising teachers

\section{INTRODUCTION}

The issue of teacher existence becomes an interesting topic to discuss, especially the problem of the existence of PE teachers who until now still cannot change its status as a marginal subject [1]. It starts from the problem of the number of teachers, competence, recruitment, dissemination, to the welfare of teachers [2]. Discussing the competence of teachers, the latest data from the minister of education of Indonesia states that, the average value of teacher competence nationally is still at 53.02, meaning that the value is still below expectations to be achieved that is equal to 55.00 [3]. This condition is feared will have an impact on the low quality of learning that will be created later. Because quality learning can only be created by teachers who have high competencies [4]. The higher the competence of teachers will be followed by the high quality of learning. The quality of learning can be demonstrated by the effectiveness of learning [5].

Problems about the quality of teachers that exist today are never separated from the contribution of Education Institute of Education Personnel (EIEP). The availability of an abundance of teachers to a teacher-student ratio of 1:16 [2], with a quality that is still far from expectations, adds more work as EIEP's responsibility as a place of learning for prospective teachers.

Talking about the quality of competence of teacher and teacher candidates, can never be separated from the assessment measures to determine the quality of the teacher candidate itself. So far, the quality of prospective teachers who are still studying at the university is represented by academic achievement in the form of Grade Point Average (GPA). Assessment of the various disciplines that build the knowledge and skills of students during the lecture becomes the benchmark of competence of prospective teachers. No doubt that the university has been trying to always keep the quality of their graduates to be ready to contribute in the world of education. Today's universities are lulled by the achievements of students represented by the high GPA of graduates. During this time, GPA is still the only benchmark assessment of universities in giving predicate to their graduates. Therefore, the important thing in the form of student competence as a teacher candidate like neglected.

The results of research on the relationship of academic achievement of PPTE students with the competence of teachers, indicating that GPA can be used as a benchmark of teacher competency quality if the assumption of long learning is considered to provide more learning experience [6]. That is, GPA cannot fully represent the competence of prospective teachers if the assumption of the longer the students study the higher the learning experience is not met. Therefore, it is not surprising that many schools requiring teachers of PE require GPAs to the applicants to work as teachers, although the results indicate that high GPA does not have a correlation to the physical conditions and skills required to become teachers at school [7]. Therefore, it is necessary to have mechanisms and/or 
other instruments to be able to really assess the quality of competence of prospective teachers.

Suroto, et al [8] have offered a way of measuring PPET competence through the instruments they have successfully compiled. The instrument is in the form of an enclosed questionnaire equipped with a structured column that shows evidence of student learning experiences demonstrating PPET competence. In addition, Suroto, et al [8] have successfully measured the competence of PPET in Surabaya which is at an average value of $58 \%$ (medium). The frame of mind built in the measurement is expected by the higher competence will be followed by the quality of learning that will be created later. In addition, in 2013, Prakoso and Hartati [5] measured the quality of learning through the effectiveness of PE learning on PPET who conducted field practice. The results showed that the quality of learning entered the category of "good", but $50 \%$ of prospective teachers conduct learning without making and using learning planning.

Agreement on the high competence of teachers will be followed by the high quality of learning done as if it has been final. Thus, the step of improving the quality of learning more done by improving the competence of the teachers first [9]. PETE becomes the institution most responsible for the quality of PE teachers who will be the teachers or who have taught. Improvement of prospective teachers who are still studying at the university is a necessity that is possible but revamping the alumni who have been teaching will bring problems. To that end, monitoring of the quality of prospective teachers must be done optimally, especially to those who enter the final year of college. One PETE program to equip PPET about the experience of knowing the school environment and learning to become a teacher at school is a Learning Management Program (LMP). The program became PETE's flagship program to improve the quality of prospective PE teachers, especially in conducting learning [10]. Therefore, the implementation of PPP is the right time to monitor the readiness of the PPET to learn the real students. This article will describe the quality of PPET students who viewed from the effectiveness of learning done when they do learning in UNESA's partner schools.

\section{METHOD}

\section{A. Participants}

It is a descriptive study involving 290 students (107 boys and 183 girls) consisting of 90 junior high school students (33 boys and 57 girls) and 200 high school students (74 boys and 126 girls) involved in the process of measuring the effectiveness of learning carried out by 10 PPET. Furthermore, as many as 7 supervising teachers from 10 students are also involved to conduct an assessment of PE learning. Assessment is done when the prospective teachers implement LMP at UNESA's partner school in junior and senior high school level in Surabaya. Student candidates who are assessed are studying in $4^{\text {th }}$ year at PETE, Universitas Negeri Surabaya. Measurements are made when the PPETs follow LMP according to the school distribution by PETE.

\section{B. Procedure}

Measurement of the effectiveness of learning is done by asking for opinions to the students and observation activities undertaken by supervising teacher. Students who provide assessments are those who have followed the lessons learned by prospective teachers. The assessment is done as soon as the students finish the learning. While the measurement of the quality of the learning process conducted supervising teacher done during the learning is done, starting from the initial stage, main, and closing. Observations use standardized instruments that have a choice of answers and a description of input for indicators that are not matched. Based on the observation guidelines, the supervising teacher will mark every indicator performed by PPET while doing the learning. For indicators that are not implemented, the supervising teacher is required to provide a useful description for improving learning in PPET.

\section{Instrumentation}

There are two instruments to be used in measuring the quality of the learning process, namely Formative Class Evaluation (FCE) questionnaires and observation sheets. FCE is an instrument consisting of 9 items of questions developed from four dimensions, namely: Product/Outcome (1. Impressive Experience; 2. Skill; and 3. Knowledge), Volition and Interest/Motivation (4. Doing One's Best and 5. Fun), Way of Learning (6. Spontaneous Learning and 7. Learning of Your), and Cooperation (8. Friendly Manner and 9. Cooperative Learning) [4]. Observations by supervising teachers were conducted using standardized observation guidelines by the Indonesian government through the 2013 curriculum. Observations were made on three learning stages, namely initial, main, and closing lessons.

\section{Data analysis}

Data analysis used is descriptive statistic and percentage

\section{RESULTS}

The results of the study explain two things, namely: FCE and observation score.

TABLE I. QUALITY OF LEARNIG REVIEWED FROM FCE SCORE

\begin{tabular}{|l|l|c|l|}
\hline Dimension & \multicolumn{1}{|c|}{ Items } & Score & Meaning \\
\hline \multirow{4}{*}{$\begin{array}{l}\text { Product/ } \\
\text { Outcome }\end{array}$} & 1. Impressive Experience & 2.75 & Excellent \\
\cline { 2 - 4 } & 2. Skill & 2.85 & Excellent \\
\cline { 2 - 4 } & 3. Knowledge & 2.88 & Excellent \\
\cline { 2 - 4 } & Score of Dimension & 2.82 & Excellent \\
\hline \multirow{3}{*}{$\begin{array}{l}\text { Volition and } \\
\text { Motivation }\end{array}$} & 4. Doing One's Best & 2.85 & Good \\
\cline { 2 - 4 } & 5. Fun & 2.93 & Good \\
\cline { 2 - 4 } Way of & Score of Dimension & 2.89 & Good \\
\hline \multirow{4}{*}{ Learning } & 6. Spontaneous Learning & 2.74 & Good \\
\cline { 2 - 4 } & 7. Learning of Your Own Goal & 2.78 & Good \\
\cline { 2 - 4 } & Score of Dimension & 2.76 & Good \\
\hline \multirow{4}{*}{\begin{tabular}{l} 
Cooperation \\
\cline { 2 - 4 }
\end{tabular}} & 8. Friendly Manner & 2.84 & Good \\
\cline { 2 - 4 } & 9. Cooperative Learning & 2.84 & Excellent \\
\cline { 2 - 4 } & Score of Dimension & 2.84 & Good \\
\hline & Total Score & 2.83 & Excellent \\
\hline
\end{tabular}


FCE score shows the quality of learning based on the opinions of students who are given shortly after following the lesson. A total score of 2.83 (excellent), product/outcome dimension score of 2.82 (excellent), volition and interest of 2.89 (good), way of learning of 2.76 (good), and cooperation of 2.84 (good). (See table I.)

Observation score shows the quality of learning based on the results of supervising teacher assessment during the learning process conducted by prospective teachers. The total score of observation result by supervising teacher is $89.7 \%$ (excellent), initial value of learning is $95.0 \%$ (excellent), main is (very good), and closing learning is $77.5 \%$ (good). (See table II.)

TABLE II. QUALITY OF LEARNIG REVIEWED FROM OBSERVATION SCORE BY SUPERVISING TEACHERS

\begin{tabular}{|l|l|l|l|}
\hline No. & \multicolumn{1}{|c|}{ Lesson Stage } & Percentage & \multicolumn{1}{c|}{ Meaning } \\
\hline 1 & Initial stage (Warming up) & 95.0 & Excellent \\
\hline 2 & Main stage & 90.8 & Excellent \\
\hline 3 & Closing stage (cooling down) & 77.5 & Good \\
\hline \multicolumn{2}{|l}{ Total score } & 89.7 & Excellent \\
\hline
\end{tabular}

\section{DISCUSSION}

FCE is a simple, practical, and valid instrument to measure the effectiveness of PE learning. In accordance with its usefulness as "formative" then the measurement of the quality of this kind of learning becomes important to be done. Then, the teachers always know the quality of teaching periodically. Therefore, the process of self-evaluation can be done at any time with the help of students as the main learning object. It is proven that the process of self-evaluation can have an impact on improving the quality of teachers competencies [11].

Based on the results of the assessment using FCE, the value of the quality of learning belongs to the excellent category. With these results, it does not mean that PPET is perfect and does not need to make improvements. It needs a thorough analysis, then any such evaluation process can have more impact on improving teacher competence and learning quality or to be more convincing in self-evaluation. Teachers need to use other instruments to determine the other components in determining the quality of learning is done. However, teachers are not expected to use FCE as the only instrument to measure the quality of the learning process. A questionnaire that has statement items and demands recognition of the filler, sometimes the level of understanding students make what is measured through FCE, is not appropriate for the purpose although it is unlikely to be happened [12].

As a supplement and reinforcement of learning quality data, it is necessary to observe activities conducted by supervising teacher to assess the quality of learning process. Observations conducted by supervising teacher is an activity to mark indicators that indicate the quality of learning when the prospective students do the learning. The results of further observations will be shown to students as an effort to fix the learning process. Therefore, it takes a great supervising teacher in order to provide an objective assessment objective and in accordance with the intent of each item indicator. The greater the supervising teacher will provide more opportunities to prospective teachers in obtaining competence as a teacher. This activity is similar to the usual peer-assessment activities of teachers through the teacher community to improve the quality of learning [13]. It demands a high objective that makes the function of evaluation can be obtained optimally. Therefore, when the teachers have been aware of the importance of selfevaluation and have high objectivity for themselves, this kind of observation activity can be replaced by analyzing video learning. This method is known as Video Tape Feedback which can evaluate performance and professional advancement [14].

With satisfactory results, it makes the impression that prospective teachers are superior students who are ready to become teachers at school. However, teachers' competency data released by the government indicate another thing, namely the competence of teachers is still far from expectations [3]. For that, it should be underlined that the most important thing in the formative assessment is the teacher's awareness of the importance of self-evaluation. Students in LMP follow not only need to gain teaching experience and get to know the school but also need to get many other competencies including ways of developing sustainable performance. Because the results show that, the longer the teacher on duty does not make the teacher more powerful in learning [15]. This may be due to the low willingness of teachers to update their knowledge and practice teaching to improve the quality of self.

Compared to the previous years, these results indicate that there is an increase in the quality of learning conducted by PPET from 2012 until now. In 2012, similar research and also using FCE, total score included in the category of good [5], while it is now included in the excellent. Finally, the teachers should adopt a hat to acknowledge PETE's success in preparing PPET in becoming a PE teacher at school, although PETE is still required to make other innovations to conduct quality assessment of PPET in an effort to monitor the development of the quality of students in studying at the university.

\section{CONCLUSION}

The quality of learning done by the students of PPET in the opinion of the students get the value of 2.80 (excellent), while according to supervising teacher learning conducted by the students of PPET has met the indicator of $89.7 \%$ (excellent). The value is a great success for students to get high scores, but if the teachers want to take advantage of more, then they need to interpret the process of assessment conducted by students and supervising teacher becomes more important. Therefore, the awareness to conduct the process of formative assessment and self-evaluation of the learning process should be introduced and familiarized early to the prospective teachers, therefore they are always oriented towards perfection when they become teachers.

\section{ACKNOWLEDGMENT}

The writer would like to thank the Dean of the Faculty of Sport Science of Universitas Negeri Surabaya who has supported the research. 


\section{REFERENCES}

[1] K. Hardman and J. Marshall, "Update on the State and Status of Physical Education World-wide," 2005.

[2] Ganefri, "Kolaborasi Strategi Pemberdayaan Lintas Institusi dan Participatory Management Menuju Sistem Rekrutmen dan Distribusi Guru yang Proporsional-Efektif di Indonesia," in Konvensi Nasional Pendidikan Indonesia (KONASPI) VIII Tahun 2016, 2016, pp. 35-40.

[3] D. Maulipaksi, "7 Provinsi Raih Nilai Terbaik Uji Kompetensi Guru 2015," Laman Kementerian Pendidikan dan Kebudayaan Indonesia, 2016. [Online]. Available: https://www.kemdikbud.go.id/main/blog/2016/01/7-provinsi-raih-nilaiterbaik-uji-kompetensi-guru-2015. [Accessed: 30-Dec-2017].

[4] Suroto, "Examining the Relationship Among Studnets' Phisical Activity Level, Students' Learning Behaviors, and Students' Formative Class Evaluation During Elementary School Physical Education Classes.," University of Tsukuba, 2005.

[5] B. B. Prakoso and S. C. Y. Hartati, "Efektivitas Pembelajaran Dikjasorkes tidak Dipengerahui Latar Belakang Guru Pemula?," Pendidik. Olahraga dan Kesehat., vol. 1, no. 1, pp. 240-246, 2013.

[6] Suroto, F. D. Khory, V. C. Dinatta, and A. Priambodo, "Core Competency Measurement Model for Prospective Physical Education Teacher," IOP Conf. Ser. Mater. Sci. Eng., vol. 180, no. 12181, pp. 1-6, 2017.

[7] J. Alysia, J. L. Caputo, and R. S. Farley, "Physical Description and Job Attainment in Physical Education," Phys. Educ., vol. 62, no. 2, pp. 96$102,2005$.

[8] Suroto, F. D. Khory, V. C. Dinata, and A. Priambodo, "Core Competency Measurement Model for Prospective Physical Education
Teacher," IOP Conf. Ser. Mater. Sci. Eng., vol. 180, no. 1, p. 12181, 2017.

[9] A. I. Şen, "Effects of peer teaching and microteaching on teaching skills of pre-service physics teachers," Egit. ve Bilim, vol. 35, no. 155, pp. 78$88,2010$.

[10] F. D. Khory, S. Hartoto, Sudarso, and B. B. Prakoso, "Persepsi Guru Pamong Terhadap Kualitas Mahasiswa Calon Guru PJOK Saat Melaksanakan Program Pengelolaan Pembelajaran di Sekolah Mitra," SPORTIF, vol. 4, no. 1, pp. 38-53, 2018.

[11] B. B. Prakoso, "Upaya Peningkatan Kualitas Proses Belajar Mengajar PJOK melalui Evaluasi Diri Guru," in Optimalisasi Hasil-Hasil Penelitian dalam Menunjang Pembangunan Berkelanjutan, 2015, no. 64 , pp. 510-523.

[12] Suroto and T. Takahashi, "Students' Physical Activity Level, Students' Learning Behavior, and their Formative Class Evaluation during Fitness Units of Elementary School Physical Education Classes," Int. J. Sport Heal. Sci., vol. 3, pp. 10-20, 2005.

[13] K. Vangrieken, C. Meredith, T. Packer, and E. Kyndt, "Teacher communities as a context for professional development: A systematic review," Teach. Teach. Educ., vol. 61, pp. 47-59, 2017.

[14] M. Anderson, R. P. Mikat, and R. Martinez, "Digital Video Production in Physical Education and Athletics," J. Phys. Educ. Recreat. Danc., vol. 72, no. 6, pp. 19-21, 2001.

[15] A. Maksum, "Kualitas Guru Pendidikan Jasmani di Sekolah: Antara Harapan dan Kenyataan,” no. 3, pp. 1-32, 2010. 